\section{Maps and Monsters}

\author{
Derrick Peterson \\ in Flat Earths and Fake footnotes
}

https://doi.org/10.54739/1trh

Imagine a map of our present ... what's the shape of the existential terrain in which we find ourselves in late modernity? Where are the valleys of despair and mountains of bliss, the pitfalls and dead ends? What are the sites of malaise and regions of doubt? Where are the spaces of meaning? Are they hidden in secluded places, or waiting to be discovered in the mundane that is always with us? Where should we look for the 'thin places' that still seem haunted by transcendence? Or have they disappeared, torn up to make way for progress and development? ... Could we imagine an existential map of our secular age that would actually help us to locate ourselves and give us a feel for where we are?

- James K. A. Smith, How Not To Be Secular ${ }^{1}$

[Eustace] read only the wrong books. They had a lot to say about exports and imports and governments and drains, but they were weak on dragons.

\section{- C.S. Lewis, The Voyage of the Dawn Treader ${ }^{2}$}

A

question thus emerges: how and why did the myth of the myth of the flat earth, start? Part of this has come down to us through the widespread and near systematic misinterpretations of a certain genre of medieval maps as being useless for navigation, the so-called mappae mundi. ${ }^{3}$ Drawn on scraps of parchment, or occasionally on vellum (calf skin, sometimes goat or other animals) treated with lime and scraped clean by a crescent-shaped blade called a lunarium (or lunellum), medieval maps drew the world with the Holy City of Jerusalem at its center. Typically oriented in a famous "T and O" pattern, the circular portrayals (hence the "O") orient themselves with East at the top and Asia sitting above the lid of a "T" trisecting the map. Europe and Africa are then placed on either side of the plunging T-stem, Europe to the North (and so, left) and Africa, South (and so, to the right). These mappae mundi ("charts of the world")

Excerpt from Flat Earths and Fake Footnotes by Derrick Peterson, (c) 2021 by Wipf and Stock Publishers, Eugene, Oregon. Used by permission. All rights reserved.

\footnotetext{
1. Smith, How Not To Be Secular, 1-2.
}

2. Lewis, The Voyage of the Dawn Treader, 87.

B. $n$ this see the definitive work of Woodward, “Medieval Mappaemundi," 286-370. Woodward, it seems to me, makes an irrefutable case both that the mappae do not represent a flat earth, and do not represent geographical ignorance. Like icons, the mappae were more about communicating important Christian stories and events to those who couldn't read.

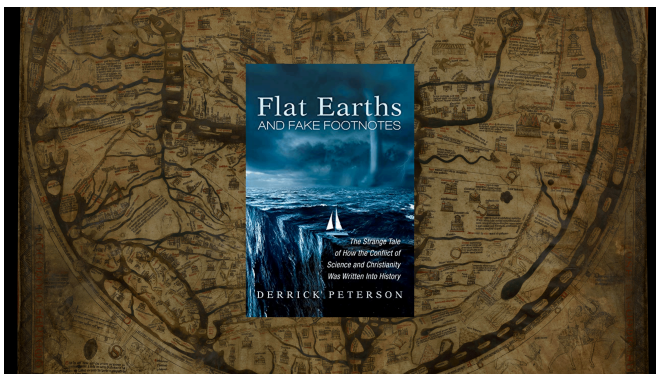

Background image is the Hereford Mappa Mundi ( Public domain, via Wikimedia Commons)

such as the Hereford map, tantalizingly place the lost Edenic paradise bound in circular flame at the top-most eastern edge, while the Pillars of Hercules line the Strait of Gibraltar at the map's bottom, and mark the western extreme of the habitable world with the words "nothing further beyond." And everywhere else along the circular courses of the mappae, monsters roam.

At times, the strange burlesque of these creatures almost appear to portend an invasion, straddling as some do the far borderlines which circumvallate the world of the map, refusing to be either solely inside or wholly outside; neither wholly natural nor wholly supernatural. ${ }^{4}$ The lines of sacred and secular also appear blurred. One finds amongst the maps like the Hereford scriptural events like the Tower of Babel, or the Jewish exodus out of Egypt. But as the viewer's eyes journey through

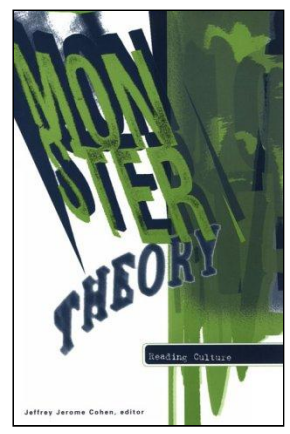
the colorful landscape, they will also run upon the golden fleece of Jason and his Argonauts, or the Cretan Labyrinth that Greek mythology tells us was built by Daedalus and populated by a particularly pugnacious minotaur. The Ebstorf map in particular gives us a clue to such juxtapositions. Named for a nunnery in Ebstorf in lower Saxony, it is an enormous drawing, sewn from the hide of thirty goats, which most scholars now estimate to have been crafted in the 13th century. Sadly, fires destroyed the original in 1943 during the Allied bombings of Hanover, Germany in World War Two. Yet, there remain several recreated colored facsimiles, along with a black and white photograph taken in 1893.

In these photographs we see at the map's eastern top Christ's disembodied (yet still rather jovial looking) head, while the northern and southern edges portray his equally disembodied hands, and the southern lip (as one might now guess), his feet. Upon further examination, these parts are not as lacking of a body as appears at first glance. Rather, as you stand back the realization hits that the whole map itself is Christ's form. His navel is Jerusalem, again at the center of the world; ${ }^{5}$ his head is Rome and the See of Peter. In other words, the map portrays the whole world along the symbolic lines of the eucharist wafer in which the world participates in Christ, ${ }^{6}$ and the

4. Cohen, “Monster Culture (Seven Theses)," 3-25. See, 7: "The monster's very existence is a rebuke to boundary and closure."

5. See Ezekiel 5:5: "I have set the city of Jerusalem in the midst of the nations and their peoples."

6. Kupfer, "Reflections on the Ebstorf Map," 110-18. 
map allows one a sort of "proxy pilgrimage" through the earth seen via the economy of salvation and lit by the light of divine life. ${ }^{7}$ From their incorporation into, and impending (re)birth from Christ's body, both the material and spiritual worlds are brought together, overcoming the lines of sacred and secular, temporal and eternal, past and present and future, nature and the supernatural. And yes, this applies even to the monsters. Thus for example in a 12th century tympanum of the Abbey church Vézalay in Burgundy, next to Christ's command "to preach the gospel to all creation" stands not just men and women, but "pygmies using ladders to mount their horses, the Panotti, with ears so huge they can use them as blankets, and, of course, the dog-heads [cynocephali]."8

$S$ the manner that they don't appear to be useful for referencing anything real. And what is real appears, well, flat. Embroidered as these maps are with their theological, philosophical, spiritual, and allegorical ornamentation; mixing together as they do time with space, present with past and future; distorting-as is their wont-topography to suite ethical and cosmological sensibilities, one could only imagine the reaction when handing this map to a boat captain or a team of explorers, and asking them to make their way in the world with it. They would want to discard all the elements that they deem fanciful, give a weak nod of approval to things that vaguely approximate the general layout of the world as we know it, and really just damn the whole thing with faint praise, perhaps by calling it "an important example of historical map-making." Or, perhaps, something much worse.

Daniel Boorstin-who, as a former Librarian of Congress, is another prestigious and well-read individual who should have known better-in his bestselling The Discoverers ${ }^{9}$ paints the pitiable portrait of a world almost too hapless to know how to move to and fro as he gestures toward the mappae: in their efforts to navigate the world travelers "did not find much help in Cosmas Indicopleustes' neat box of the universe ... The outlines of the seacoast ... could not be modified or ignored by what

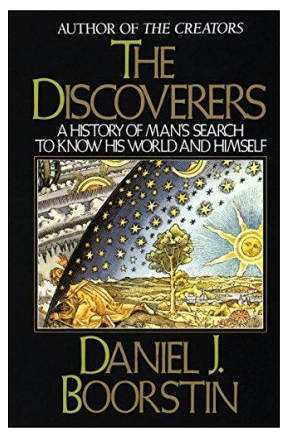
was written in Isidore of Seville or even in

Saint Augustine ... The schematic Christian T-O map was little use to Europeans seeking an eastward sea passage to the Indies." ${ }^{10}$ Such oafish ineptitude was born, he says, by "a Europe-wide phenomenon of scholarly amnesia ... afflict[ing] the continent from A.D. 300 to at least 1300. During those centuries the Christian faith and dogma suppressed the useful image of the world that had been so painfully, and so scrupulously drawn by the ancient geographers." ${ }^{11}$ This he called the "great interruption" of ancient learning, caused by the glut of Christian geographical fanatics rushing to touch the hem of their master's garment, a sixth-century eccentric known as Cosmas

\footnotetext{
7. Kupfer, “Ebstorf Map,” 119.

8. Bartlett, The Natural and the Supernatural, 100

9. Boorstin, The Discoverers.

10. Boorstin, The Discoverers, 146-49.

11. Boorstin, The Discoverers, 100.
}

(mentioned in the quote above). "After Cosmas" he says, "came a legion of Christian geographers, each offering his own variant on the scriptural plan [of the world as flat]."12 Being no less than the 12th officially appointed Librarian of Congress, it seems reasonable that Boorstin should have known better. Yet, he did not; and so neither do we. An initial trouble here, we should point out so we may bracket it until a bit later, is that Cosmas Indicopleustas was completely unknown until he was rediscovered in 1706. And even then it would be nearly two hundred years before it was argued in hindsight that Cosmas was a representative of the middle ages on this view: "No medieval author knew Cosmas, and his text was considered an authority of the 'Dark Ages' only after its English publication in 1897!” as Umberto Eco remarks. ${ }^{13} \mathrm{~A}$ nonexistent mob of flatland geographers are thus argued by Boorstin to be led by a ghostly figure they would not have recognized.

Regardless, interpreting these medieval maps as failed early attempts at topography (or repression of Greek learning) is extremely wrongheaded from the start. ${ }^{14}$ Charles Raymond Beazley dismisses the mappae for example, by charging that one need only look at the "monstrosities of the Hereford or the Ebstorf" to see that they are "of ... complete futility." ${ }^{15}$ One is reminded of J.R.R. Tolkien's famous essay on the poem Beowulf. ${ }^{16}$ Tolkien chides many critics who take Beowulf merely as an item of philological and historical significance while being practically embarrassed at the presence of Grendel, or the dragon, as a sort of aesthetic mistake that we moderns must condescend to overlook. Tolkien states, rather "the monsters are not an inexplicable blunder of taste; they are essential, fundamentally allied to the underlying ideas of the poem, which gives it its lofty tone and high seriousness." ${ }^{17}$ Contemporary scholars suffer by "placing the unimportant things at the centre, and the important on the outer edges" he says. ${ }^{18}$ Just so, when the poet of Beowulf writes of "the mighty men upon the earth," this is not, in the taste of future science, somehow at odds and obscured by a monstrous presence best pruned by we who, in later ages, are wise and see the hard earth and the bare stone for what they really are. The sense of the phrase "mighty men upon the earth" depends on the sinister presence of monsters out in the world; it is meant to summon the image of "eormengrund, the great earth, ringed by garsecg, the shoreless sea," and beneath "the sky's inaccessible roof." Thus these men, tormented by Grendel, gather "as in a little circle of light about their halls, great men with courage as their stay went forward to that battle with the hostile world and the offspring of the dark which ends for all, even kings, in defeat." ${ }^{19}$ Tolkien thus concludes "That even this 'geography,' once held as material fact could now be classed as a mere folk-tale matters very little ... [For] astronomy has done [nothing] to make the island feel more secure, or the outer seas less formidable."20

\footnotetext{
12. Boorstin, The Discoverers, 107-9.

13. Eco, "The Force of Falsity," 5.

14. Tattersall, “Sphere or Disc?” 31-46, esp. 41-44 on the mappae.

15. Quoted in Woodward, "Medieval Mappaemundi," 288.

16. Tolkien, "Beowulf: The Monsters and the Critics," 5-48.

17. Tolkien, "Beowulf: The Monsters and the Critics," 19.

18. Tolkien, "Beowulf: The Monsters and the Critics," 5.

19. Tolkien, "The Monsters and the Critics," 5.
} 
However odd such symbolic references might seem to us, then, it is not as out of the ordinary as we think. As Mark Johnson and George Lakoff write, even our routine conceptual systems (to say nothing of monsters on maps) "in terms of which we both think and act, [are] fundamentally metaphorical in nature. The concepts that govern our thought are not just matters of the intellect. They also govern our everyday functioning, down to the most mundane details. Our concepts structure what we perceive, how we get around in the world, and how we relate to other people [and other communities]." 21 Which is to say, even our modern conceptual maps have monsters, regardless of how often we acknowledge that fact. Today, the "monsters" of theology, religion, the historical period of the Middle Ages (and so on) are put on the edges of our contemporary "scientific" conceptual maps for the same reason that the older monsters of medieval maps roamed the edges: they signaled "a category crisis," as Jerome Cohen puts it. We merely happen to be much less forthcoming on such matters than our ancestors. When theology and religion are understood to constitute a vital part of the total apparatus by which the adventure of human exploration and understanding peer into the world, they thereby threaten the modern "purity" and separation of our disciplinary categories. This is, indeed, exactly what has happened in many cases. Kathleen Biddick minces no words here about the general trend: "One sign of trouble in recent histories of medieval studies is their tendency to be paradoxically yoked to the scientific victors of the nineteenth century." 22

20. Tolkien, "The Monsters and the Critics," 5. Cf. Woodward, "Reality, Symbolism, Time and Space in Medieval World Maps," 510-21.

21. Johnson and Lakoff, “Conceptual Metaphors in Everyday Language.”

\section{References}

Smith, James K.A. How Not To Be Secular: Reading Charles Taylor (Grand Rapids: Eerdman's Publishing 2014).

Lewis, C.S. The Voyage of the Dawn Treader (New York: Scholastic, 1987).

Woodward, Daniel. “Medieval Mappaemundi,” in J.B. Harley and David Woodward, eds., The History of Cartography: Cartography in Prehistoric, Ancient, and Medieval Europe and the Mediterranean vol. 1 (Chicago: University of Chicago Press, 1987), 286-370.

Cohen, Jeffrey Jerome. “Monster Culture (Seven Theses)," in Jeffrey Jerome Cohen, ed., Monster Theory: Reading Culture (Minneapolis: University of Minnesota Press, 1996), 3-25.

Kupfer, Marcia “Reflections on the Ebstorf Map: Cartography, Theology, and Delectio Speculationis,” in Keith D. Lilley, ed., Mapping Medieval Geographies: Geographical Encounters in the Latin West and Beyond, 300-1600. (Cambridge: Cambridge University Press, 2013), 110-118.

Bartlett, Robert. The Natural and the Supernatural in the Middle Ages. (Cambridge: Cambridge University Press, 2008).
While it isn't Biddick's point per se, for our story the fascinating twist turns out to be that not just the flat earth, but indeed the warfare metaphor blanketed over history are themselves one more map full of monsters. Both the flat earth and the warfare metaphor have common origins as artifacts of the emerging professional battles to seize social power and define the role of the "scientist" in Victorian England, and across the pond in America. Perhaps to

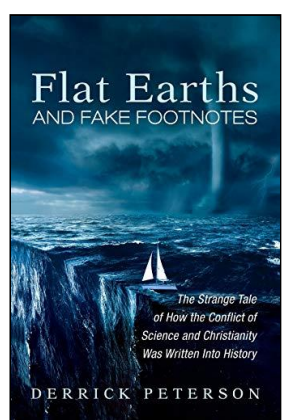
no one's surprise the nineteenth century debates over evolution are in one sense a key factor responsible for the concept of warfare between science and Christianity, but not in a way one would initially expect. In the effort to seize the rhetorical high-ground as we saw with Huxley, Tyndall, White, Draper, Youmans, and others, a campaign to turn evolution-and science at large-against institutional theology was one of the key wedges in the power shifts of professionalization began, of which absurd pictures like the flat earth were also marshalled in order to perform a flanking action to demonstrate the absurd pedigree of the Church's decision making. Thus, while the flat earth is in no sense uniquely causative of the notion of warfare, it provides one unique and fascinatingly weird angle to enter into the construction and deconstruction of the warfare metaphors organizing our historical maps.

22. Biddick, The Shock of Medievalism, 2.

Boorstin, Daniel. The Discoverers: A History of Man's Search to Know His World and Himself. (New York: Vintage Books, 1985).

Eco, Umberto. “The Force of Falsity” in Serendipities: Language and Lunacy (New York: Columbia University Press, 1998).

Tattersall, Jill. "Sphere or Disc? Allusions to the Shape of the Earth in Some Twelfth-Century and Thirteenth-Century Vernacular French Works." The Modern Language Review 76 no.1 (1981): 31-46.

Tolkien, J.R.R. “Beowulf: The Monsters and the Critics.” Proceedings of the British Academy 22 (1936): 245-295.

Woodward, Daniel. “Reality, Symbolism, Time and Space in Medieval World Maps," Annals of the Association of American Geographers 75 (1985): 510-521.

Johnson, Mark and Lakoff, George. "Conceptual Metaphor in Everyday Language.” The Journal of Philosophy 77 no.8 (1980):453-486.

Biddick, Kathleen. The Shock of Medievalism (Durham: Duke University Press Books, 1998). 